\title{
KAJIAN KEAMANAN OBAT ANTIHIPERTENSI PADA PASIEN PENYAKIT GINJAL KRONIK
}

\author{
Inayatush Sholihah ${ }^{1}$, Hanugrah Ardya $C S^{2}$ \\ Fakultas Ilmu Kesehatan, Universitas Kusuma Husada, Surakarta ${ }^{12}$ \\ e-mail: ${ }^{1}$ inayatush@ukh.ac.id, ${ }^{2}$ hanugrahardya8@gmail.com
}

\begin{abstract}
Patients with Chronic kidney disease (CKD) and hypertension often receive combination of antihypertensive drugs to achieve optimal blood pressure targets. The use of this combination of drugs can trigger adverse drug reaction (ADR). This study aimed to determine the safety of antihypertensive drugs in CKD patients, including the pattern of use and assessment of side effects. Data were collected from medical records of chronic kidney disease patients at RSUD Ir. Soekarno Sukoharjo during January 2019 to January 2020. WHO Causality Category was used to assess the probability of side effects. A total of 52 patients were included in this study. There were 8 patients (15.34\%) experiencing possible side effects, consisting of bisoprolol (1 event), amlodipine (5 events), furosemide (1 event), and valsartan (1 event). The most widely used antihypertensive drug combinations are ARBs, CCBs, and diuretics.
\end{abstract}

Keywords: ADR, side effects, antihypertensive drugs, chronic kidney disease

\begin{abstract}
ABSTRAK
Pasien penyakit ginjal kronik (PGK) dengan hipertensi seringkali memperoleh kombinasi obat antihipertensi untuk mencapai target tekanan darah. Penggunaan kombinasi obat ini dapat memicu terjadinya Reaksi Obat yang Tidak Dikehendaki (ROTD). Penelitian ini bertujuan untuk mengetahui keamanan penggunaan obat antihipertensi pada pasien PGK yang meliputi pola penggunaan dan pengkajian efek samping. Pengambilan data dilakukan dari rekam medik pasien penyakit ginjal kronik yang menjalani rawat jalan di Rumah Sakit Umum Daerah (RSUD) Ir. Soekarno Sukoharjo selama periode Januari 2019 sampai dengan Januari 2020. Pengkajian probabilitas efek samping menggunakan algoritma Kausalitas WHO. Dari 52 subyek penelitian, terdapat 8 pasien $(15,34 \%)$ mengalami kemungkinan efek samping, terdiri dari bisoprolol (1 kejadian), amlodipin (5 kejadian), furosemid (1 kejadian), dan valsartan (1 kejadian). Kombinasi obat antihipertensi yang paling banyak digunakan adalah ARB, CCB, dan diuretik.
\end{abstract}

Kata Kunci: ROTD, efek samping, obat antihipertensi, penyakit ginjal kronik

\section{PENDAHULUAN}

PGK merupakan masalah kesehatan di negara maju dan negara berkembang. Berdasarkan National Chronic Kidney Disease Fact Sheet 2014 yang dikeluarkan oleh Center for Disease Control and Prevention (CDC), lebih dari $10 \%$ atau lebih dari 20 juta orang dewasa di Amerika mengalami PGK dengan berbagai macam tingkat keparahan. ${ }^{(2)} \mathrm{Di}$ Indonesia, hasil Riset Kesehatan Dasar tahun 2018 menunjukkan prevalensi PGK masih tinggi yaitu sebesar 3,8\% atau mengalami kenaikan sebesar $1,8 \%$ dari tahun 2013. ${ }^{(4)}$

Kondisi penyakit ginjal dapat mempengaruhi kadar obat dalam darah yang berkaitan dengan perubahan parameter farmakokinetik seperti absorbsi obat, distribusi, ikatan protein, metabolisme dan ekskresi obat melalui ginjal. ${ }^{(3)}$ Klirens kreatinin menggambarkan fungsi ginjal untuk mengekskresikan obat. Klirens kreatinin yang rendah dapat meningkatkan resiko toksisitas obat. Penyakit ginjal juga mempengaruhi metabolisme obat oleh hati melalui pengaruh dari uremia yang disebabkan oleh gangguan ginjal. ${ }^{(10)}$ Uremia menyebabkan perubahan ikatan protein plasma dengan obat. Pada pasien dengan penyakit ginjal, metabolisme obat di hati juga terganggu dengan mekanisme gangguan pada transporter obat dan enzim metabolik sehingga dapat menyebabkan penurunan klirens obat. ${ }^{(7)}$

Hipertensi adalah penyakit yang sering menyertai pasien PGK karena saling berhubungan secara patofisiologi. Prevalensi hipertensi pada PGK adalah sebesar 60-90\%. Hipertensi yang tidak terkontrol menyebabkan peningkatan morbiditas dan mortalitas kardiovaskuler, dan merupakan salah satu penyebab terjadinya gagal ginjal terminal. ${ }^{(5)}$ Untuk mencapai target tekanan darah $<140 / 90 \mathrm{mmHg}$ pada

pasien PGK dengan hipertensi lebih sulit dibandingkan pada pasien dengan hipertensi saja. Oleh sebab itu, seringkali pasien PGK dengan hipertensi memperoleh kombinasi obat antihipertensi untuk mencapai target tekanan darah. Penggunaan 
kombinasi obat ini dapat memicu terjadinya Reaksi Obat yang Tidak Dikehendaki (ROTD).

Dalam tata laksana terapi, manfaat dan keamanan suatu obat menjadi pertimbangan penting yang tidak dapat dipisahkan. Evaluasi mengenai manfaat dan keamanan suatu obat berguna untuk mencapai tujuan utama yaitu terapi yang aman dan efektif bagi pasien. Mekanisme pengamanannya berupa pemantauan ROTD yang meliputi efek samping, interaksi obat dan kontraindikasi.

Berdasarkan latar belakang tersebut maka diperlukan suatu penelitian yang mengkaji mengenai keamanan penggunaan obat antihipertensi pada pasien PGK yang meliputi pola penggunaan dan pengkajian efek samping obat.

\section{METODE}

Penelitian ini merupakan penelitian deskriptif analitik dengan rancangan cross sectional.Pengambilan data secara retrospektif.Penelitian dilaksanakan pada bulan Juli September 2020 di RSUD Ir. Soekarno Sukoharjo. Subyek penelitian adalah pasien PGK yang menjalani rawat jalan dari Januari 2019 - Januari 2020 dan memenuhi kriteria inklusi dan eksklusi. Kriteria inklusi meliputi pasien terdiagnosis PGK dengan hipertensi, berusia minimal 18 tahun, dan memperoleh terapi dengan antihipertensi. Kriteria eksklusi meliputi pasien dengan riwayat penyakit gangguan fungsi hati, pasien penderita Human Immunodeficiency Virus (HIV) Acquired Immunodeficiency Syndrome (AIDS), pasien yang sedang menjalani kemoterapi, dan pasien dengan transplantasi ginjal.

Pengambilan data dilaksanakan dengan pengumpulan data dari rekam medik, yang meliputi karakteristik pasien (usia, jenis kelamin, jumlah penyakit, jumlah obat, durasi pemakaian obat antihipertensi), keluhan atau gejala yang muncul, obat-obat yang dikonsumsi dan hasil laboratorium. Pengkajian keamanan dilakukan dengan parameter adanya gejala dan tanda klinis yang berkaitan dengan efek samping obat-obat antihipertensi. Pengkajian probabilitas efek samping dilakukan dengan Kategori Kausalitas WHO.

\section{HASIL}

\section{Karakteristik Subyek Penelitian}

Pelaksanaan penelitian dilakukan pada bulan Juli sampai dengan September 2020 di RSUD Ir. Soekarno Sukoharjo dengan subyek penelitian sebanyak 52 pasien. Dari 52 pasien, jumlah pasien laki-laki lebih besar daripada perempuan yaitu terdiri dari 30 laki-laki $(57,69 \%)$ dan 22 perempuan $(42,31 \%)$. Rata-rata pasien berusia 47 tahun. Golongan usia terbanyak adalah 35 - 44 tahun.

Keseluruhan pasien memiliki diagnosis penyakit ginjal kronik dengan hipertensi. Penyakit penyerta yang diderita pasien antara lain 19 pasien $(36,54 \%)$ dengan diabetes mellitus (DM) dan 33 pasien $(63,46 \%)$ dengan penyakit lain selain DM seperti Chronic Heart Failure (CHF), Ischaemic HeartDisease (IHD) dan angina pektoris.

Sebanyak 48 pasien $(92,31 \%)$ menggunakan lebih dari 5 jenis obat. Penggunaan $>5$ jenis obat dalam suatu terapi disebut dengan polifarmasi. Gambaran umum subyek penelitian selengkapnya ditampilkan pada tabel 1 .

Tabel 1 Karakteristik Subyek Penelitian

\begin{tabular}{|c|c|c|c|}
\hline No. & Jenis Kelamin & Frekuensi & Presentase \\
\hline \multirow[t]{3}{*}{1} & \multicolumn{3}{|l|}{ Jenis Kelamin } \\
\hline & Laki-laki & 30 & 57,69 \\
\hline & Perempuan & 22 & 42,31 \\
\hline \multirow[t]{7}{*}{2} & \multicolumn{3}{|l|}{ Usia (tahun) } \\
\hline & remaja akhir (15-25) & 2 & 3,85 \\
\hline & dewasa awal (26-35) & 8 & 15,38 \\
\hline & $\begin{array}{l}\text { dewasa akhir (36- } \\
45)\end{array}$ & 14 & 26,92 \\
\hline & lansia awal (46-55) & 12 & 23,08 \\
\hline & lansia akhir (56-65) & 11 & 21,15 \\
\hline & manula $(\geq 65)$ & 5 & 9,62 \\
\hline \multirow[t]{3}{*}{3} & \multicolumn{3}{|c|}{ Jenis Penyakit Penyerta } \\
\hline & DM & 19 & 36,54 \\
\hline & Non DM & 33 & 63,46 \\
\hline \multirow[t]{3}{*}{4} & \multicolumn{3}{|l|}{ Jumlah Obat } \\
\hline & $1-4$ & 4 & 7,69 \\
\hline & $\geq 5$ & 48 & 92,31 \\
\hline \multirow[t]{3}{*}{5} & \multicolumn{3}{|c|}{ Durasi pemakaian Antihipertensi } \\
\hline & $<1$ tahun & 10 & 19,23 \\
\hline & $>1$ tahun & 42 & 80,77 \\
\hline
\end{tabular}

\section{Pola Penggunaan Obat Antihipertensi}

Obat antihipertensi yang digunakan bervariasi mulai dari tunggal hingga 6 kombinasi. Kombinasi obat antihipertensi yang paling banyak digunakan adalah ARB, CCB, dan diuretik. Kombinasi ini digunakan oleh 12 pasien $(23,08 \%)$. Gambaran penggunaan obat antihipertensi selebihnya dapat dilihat pada tabel 2 .

Tabel 2. Pola Penggunaan Obat Antihipertensi pada Pasien PGK

\begin{tabular}{|c|l|c|c|}
\hline No. & Kombinasi Obat & Jumlah & $\begin{array}{c}\text { Persentase } \\
(\boldsymbol{\%})\end{array}$ \\
\hline 1 & ARB, CCB & 6 & 11,54 \\
\hline 2 & $\begin{array}{l}\text { ARB, CCB, Beta } \\
\text { blocker }\end{array}$ & 2 & 3,85 \\
\hline 3 & ARB, CCB, Diuretik & 12 & 23,08 \\
\hline 4 & $\begin{array}{l}\text { ARB, CCB, Diuretik, } \\
\text { Beta bloker }\end{array}$ & 7 & 13,46 \\
\hline 5 & $\begin{array}{l}\text { ARB, CCB, Diuretik, } \\
\text { Beta bloker, Nitrat }\end{array}$ & 5 & 9,62 \\
\hline 6 & ARB, CCB, Beta & 2 & 3,85 \\
\hline
\end{tabular}




\begin{tabular}{|c|c|c|c|}
\hline No. & Kombinasi Obat & Jumlah & $\begin{array}{c}\text { Persentase } \\
(\%)\end{array}$ \\
\hline & blocker, Nitrat & & \\
\hline 7 & $\begin{array}{l}\text { ARB, CCB, Diuretik, } \\
\text { Nitrat }\end{array}$ & 1 & 1,92 \\
\hline 8 & $\begin{array}{l}\text { ARB, CCB, Diuretik, } \\
\text { Alfa blocker }\end{array}$ & 3 & 5,77 \\
\hline 9 & $\begin{array}{l}\text { ARB, CCB, Diuretik, } \\
\text { Alfa bloker, Nitrat }\end{array}$ & 1 & 1,92 \\
\hline 10 & $\begin{array}{l}\text { ARB, CCB, Alfa } \\
\text { blocker }\end{array}$ & 1 & 1,92 \\
\hline 11 & ARB, Diuretik & 1 & 1,92 \\
\hline 12 & $\begin{array}{l}\text { ARB, Diuretik, } \\
\text { Nitrat }\end{array}$ & 2 & 3,85 \\
\hline 13 & $\begin{array}{l}\text { ARB, ACEI, CCB, } \\
\text { Diuretik, Beta } \\
\text { Blocker, Nitrat } \\
\end{array}$ & 1 & 1,92 \\
\hline 14 & Diuretik & 3 & 5,77 \\
\hline 15 & Diuretik, Nitrat & 1 & 1,92 \\
\hline 16 & ACEI, CCB & 2 & 3,85 \\
\hline 17 & $\begin{array}{l}\text { ACEI, CCB, } \\
\text { Diuretik, Alfa } \\
\text { blocker, Nitrat }\end{array}$ & 1 & 1,92 \\
\hline 18 & $\begin{array}{l}\text { ACEI, CCB, } \\
\text { Diuretik, Beta bloker }\end{array}$ & 1 & 1,92 \\
\hline \multicolumn{2}{|r|}{ Total } & 52 & 100 \\
\hline
\end{tabular}

\begin{tabular}{|c|c|c|c|c|}
\hline No. & Obat & Efek Samping & Kejadian & $\begin{array}{c}\text { Analisis } \\
\text { WHO }\end{array}$ \\
\hline 1 & Bisoprolol & $\begin{array}{l}\text { Bronkospasme } \\
\text { (sesak nafas) }\end{array}$ & 1 & Probable \\
\hline \multirow{4}{*}{2} & \multirow{4}{*}{ Amlodipin } & Sakit kepala & 2 & Possible \\
\hline & & Konstipasi & 1 & Possible \\
\hline & & $\begin{array}{l}\text { Nyeri } \\
\text { punggung }\end{array}$ & 1 & Probable \\
\hline & & $\begin{array}{l}\text { Rasa tidak } \\
\text { nyaman di } \\
\text { perut }\end{array}$ & 1 & Probable \\
\hline 3 & Furosemid & Hiponatremia & 1 & Probable \\
\hline 4 & Valsartan & Hiperkalemia & 1 & Probable \\
\hline \multicolumn{3}{|c|}{ Total Kejadian } & 8 & \\
\hline
\end{tabular}

\section{PEMBAHASAN}

Hasil penelitian menunjukkan jumlah pasien pada usia 35-54 tahun juga cukup tinggi.Peningkatan kejadian PGK pada rentang usia ini kemungkinan disebabkan karena peningkatan prevalensi diabetes dan hipertensi pada usia dewasa muda di mana diabetes dan hipertensi merupakan penyebab utama PGK. ${ }^{(8)}$ Berdasarkan penelitian ini jenis kelamin laki laki lebih dominan dibandingkan perempuan. Hasil ini sesuai dengan Silbiger dan Neugarten (2008) bahwa

\section{Kejadian Efek Samping Obat Antihipertensi} pada Pasien PGK

Pada penelitian ini terdapat 8 pasien $(15,38 \%)$ mengalami sedikitnya satu efek samping yang dipertimbangkan berkaitan dengan penggunaan obat antihipertensi, yaitu: bisoprolol (1 kejadian), amlodipin (5 kejadian), furosemid (1 kejadian), dan valsartan (1 kejadian). Efek yang muncul adalah sesak nafas (bisoprolol), sakit kepala, konstipasi, nyeri punggung, dan rasa tidak nyaman di perut (amlodipin), hiponatremia (furosemid),dan hiperkalemia (valsartan). Gambaran kejadian efek samping selebihnya dapat dilihat pada tabel 3 .

Tabel 3. Kejadian Efek Samping Penggunaan Obat Antihipertensi pada Pasien PGK nefropati membran dan penyakit ginjal kronik lebih rentan pada pria dibandingkan wanita. ${ }^{(6)}$

Menurut JNC VIII, tata laksana terapi hipertensi pada PGK dengan atau tanpa diabetes adalah dengan Angiotensin Converting Enzyme (ACEI) dan Angiotensin II Receptor Blockers (ARB) tunggal atau dengan kombinasi dengan obat lain. Golongan obat ini memiliki sifat renoprotektif dan kardioprotektif yang bermanfaat untuk pasien penyakit ginjal. JNC VIII menyarankan untuk memaksimalkan dosisobat tunggal maupun kombinasi dua obat terlebih dahulu. Namun jika diperlukan dapat ditambahkan obat ketiga dari golongan lain (beta bloker, alfa blocker, central bloker, dan antagonis aldosterone). ${ }^{(9)}$

Pemilihan kombinasi obat antihipertensi disesuaikan dengan kondisi pasien dan efektivitas penurunan tekanan darah. Untuk mencapai tekanan darah yang optimum pada pasien PGK lebih sulit dibandingkan pada pasien dengan hipertensi saja. Oleh sebab itu diperlukan kombinasi obat antihipertensi. Penggunaan kombinasi obat dapat memicu terjadinya reaksi obat yang tidak dikehendaki.

Pada penelitian ini bisoprolol menyebabkan kejadian sesak nafas atau bronkospasme. Bisoprolol merupakan obat antihipertensi golongan beta bloker kardio-selektif. Reseptor $\beta 1$ adrenergik terutama 
ditemukan di jaringan jantung, sedangkan reseptor $\beta 2$ adrenergik banyak ditemukan di bronkus.Blokade pada reseptor $\beta 2$ adrenergik menyebabkan bronkospasme. Seharusnya beta bloker kardio-selektif tidak menimbulkan efek samping bronkospasme karena aksinya selektif di jatung. Namun beberapa penelitian, golongan beta bloker kardioselektif masih dapat menimbulkan efek samping bronkospasme yang reversibel. ${ }^{(1)}$

Furosemid adalah golongan diuretik yang memiliki kemampuan untuk meningkatkan ekskresi natrium dalam urin dan mengurangi retensi cairan pada pasien penyakit ginjal. Efek samping obat ini yakni menyebabkan produksi urin lebih banyak sehingga dapat membuang air dan natrium berlebih dalam tubuh, yang disebabkan oleh kondisi seperti gagal jantung, penyakit hati, dan penyakit ginjal. Kehilangan natrium secara berlebihan dapat menyebabkan hiponatremia. Hal ini terlihat dari kadar natrium pasien adalah $125 \mathrm{mEq} / \mathrm{L}$.

Penyakit ginjal merupakan salah satu penyebab paling umum hiperkalemia. Ketika fungsi ginjal terganggu, ginjal tidak mampu membuang kelebihan kalium dalam tubuh. Selain itu, hiperkalemia pada PGK juga dapat dipicu oleh penggunaan golongan obat yang dapat menginduksi hiperkalemia. Obat yang bekerja pada sistem renin angiotensin aldosteron seperti valsartan dapat menyebabkan terjadinya hiperkalemia. Obat ini menyebabkan berkurangnya produksi aldosteron sehingga menyebabkan terjadinya penurunan sekresi ion kalium di ginjal.Kondisi ini menyebabkan jumlah kalium dalam tubuh meningkat. Pada penelitian ini pasien mengalami hiperkalemia sedang dengan kadar kalium 6,7 mmol/L.

\section{KESIMPULAN}

Pada penelitian ini menunjukkan efek samping yang paling umum terjadi adalah sakit kepala karena penggunaan amlodipin.

\section{DAFTAR PUSTAKA}

1. Ahmed, R. \& Howard, M. Reversible bronchospasm with the cardio-selective betablocker celiprolol in a non-asthmatic subject. Respiratory Medicine CME. 2009; 2:141-143.

2. Center for Disease Control and Prevention (CDC). National Chronic Kidney Disease Fact Sheet. 2014 [cited 2020 Aug 05]. Available from: http://www.cdc.gov/diabetes/pubs/pdf/kidney_fact sheet.pdf.

3. Hassan, Y., Al-Ramahi, R.J., Aziz, N.A. \& Ghazali, R. Adverse drug events in hospitalized patients with chronic kidney disease. International Journal of Clinical Pharmacology and Therapeutics. 2010; 48(9): 571-576.
4. Kementerian Kesehatan Republik Indonesia. Riset Kesehatan Dasar (RISKESDAS). Jakarta: Kementerian Kesehatan RI. 2018.

5. Ku, E., Lee, B.J., Wei, J., et al. Hypertension in CKD: Core Curriculum 2019. Am J Kidney Dis. 2019;74:120-131.

6. Silbiger, S., dan Neugarten, J. Gender and human chronic renal disease. Gend Med. 2008; 5 Suppl A:S3-S10.

7. Sun, H., Frassetto, L., Benet, L.Z.. Effects of Renal Failure on Drug Transport and Metabolism. Pharmacol Ther. 2006; 109:1-11.

8. The National Institute of Diabetes and Digestive and Kidney DiseasesHealth Information Center. US Renal Data System 2019 Annual Data Report: Epidemiology of Kidney Disease in the United States. AJKD. 2020; 75(1):1-10.

9. U.S. Department of Health and Human Services. The Eight Report of the Joint National Committee on, Prevention, Detection, Evaluation, and Treatment of High Blood Pressure. NIH Publication. 2011; 04-5230

10. Venitz, R. Effect of Chronic Renal Failure on the Disposition of Highly Hepatically Metabolized Drugs. Int J Clin Pharmacol Ther. 2000; 38: 245253. 